\title{
THE 20 KEYS METHODOLOGY - CONTINUOUS IMPROVEMENT FOR ORGANIZATIONAL EFFICIENCY
}

\author{
Aleksandar ERCEG * \\ Josip Juraj Strossmayer University of Osijek, Croatia \\ Predrag DOTLIĆ \\ University Hospital Osijek, Croatia \\ Monika MIKUŠ \\ Entrepreneurial Center, Croatia
}

\begin{abstract}
Increased organizational efficiency should be one of the main strategic goals of every business. Ways of achieving it differ and one of the many choices is to improve business operations using available tools such as the "20 keys methodology". This methodology is used to achieve strategic goals through the enhanced speed of learning and innovation. The aim of this paper is to look at the potential of 20 keys methodology for the improvement of company's organizational efficiency in today's global market. This integrated set of different tools is intended to increase the company's efficiency and level of quality with synchronized cost reduction. 20 keys tend to eliminate various "wastes" in production processes to improve buyer's satisfaction and motivate employees to act towards achieving company's goals. Eventually, the methodology application should ensure a sustainable development, profitability, and integrated approach to competitiveness and long-term success of the company. The paper examines the implementation of the 20 keys methodology in Croatia and presents one case of a local production company using the methodology aiming to increase the organizational efficiency. Further research proposals are brought to confirm the potential influence of methodology on organizational efficiency.
\end{abstract}

JEL classification: D24, M29, O33

Keywords: process improvement, operations management, 20 keys methodology, cost reduction, organizational efficiency

*Corresponding author. Address: Josip Juraj Strossmayer University of Osijek, Faculty of Economics in Osijek, Trg Ljudevita Gaja 7, 31000 Osijek, Croatia, Tel. +38531224426, Email: aerceg@efos.hr 


\section{Introduction}

Due to a growing complexity of businesses eco-systems, companies don't compete anymore only by prices of their products or services but also by the capability to recurrently improve their processes and products (Teece, 2007). Companies are trying to improve their organizational efficiency by improving their processes which can lead to lower prices of the final product or service. Further on, it is necessary to create and maintain a positive attitude of employees and finally to assure the top management support (Ivanova et al. 2014). To achieve these goals, certain management tools and methodologies can be (and are) used. Some of the most well-known ones include ISO standards (especially standards ISO 9000 and ISO 14000), Balanced Scorecard; Business Process Reengineering or Business Process Improvement, European Production System, Lean Manufacturing, Just in Time, Continuous Process Improvement, Single Minute Exchange of Dies, Total Quality Management, Total Productive Maintenance.

Although these approaches can help companies in the endeavor to continuously improve their processes, products, and services, some of the approaches are more common to the product-oriented companies and some are more common to the service-oriented companies. It is important to state that companies are always trying to find an approach which is the most suitable for their needs. Companies are trying to be better from inside through better operations management (of their processes). Thus, it is important for the companies to have an operational strategy of continuous incremental improvement (Gilmore, 1990).

During the first decade of the $21^{\text {st }}$ century, the 20 keys methodology was introduced in Croatia and several companies implemented some of the "keys" aiming to improve their organizational efficiency. This paper aims to explore the importance of the 20 keys methodology as a way of continuous improvement and increasing organizational efficiency. After the introduction, we define continuous improvement and state its characteristics. In the next part, 20 keys methodology is defined, and all keys are presented. Fourth part gives an example of a Croatian company which has implemented 20 keys methodology and shows how this tool has influenced their organizational efficiency. Finally, in the last part, we will present the conclusion and give recommendations for further research on this important topic.

\section{Continuous improvement and organizational efficiency}

\subsection{Continuous improvement definition and characteristics}

Continuous improvement is a broadly used expression which has been used to describe different meanings in today's economy. Some people see continuous improvement as a synonym to innovation since it can be connected to the pursuit of better service, processes and products, some connect it to organizational renewal or redesign programs and for some, it relates to a quality improvement and waste reduction (Besant and Cafyn, 1997). Its roots can be found in the initiatives of several companies made in the 1800s (Bhuiyan and Baghel, 2005). These authors also stated that early continuous improvement activities were connected to different principles in relation to work improvements, while today's continuous improvement is more connected to planned activities. Continuous improvement is a holistic concept and therefore it is not strictly limited to any precise activity, department, or function in the 
company (Gilmore, 1990). Improvements can be made all over the company from the production line and warehouse, maintenance to the offices and support activities. Thus, the possibilities to improve operations within the company are endless. Continuous improvement can be defined as an integration of organizational philosophy, techniques, and structure to achieve sustained performance improvements in all activities on an interrupted basis (Gilmore, 1990: 21). Anand et al. (2009: 444) defined continuous improvement as a systematic effort to seek out and apply new ways of doing work i.e. actively and repeatedly making process improvements. As the company accepts continuous improvement as organization-wide approach it results in improved quality of doing business which eventually leads to a reduction of expenditures for quality and finally to increased company's competitiveness. Bessant defined continuous improvement as a company-wide process of focused and continuous incremental innovation (Bessant et al, 1994: 18). This definition presents incremental innovations as continuous improvement dynamo and they are represented by small step advancements and shortchanges cycles which, if observed separately, have a small effect but as a system induce a substantial influence on overall company's performance. Some authors (Besant et al., 1994; Bessant and Caffyn, 1997) have shown the need for a different approach to the implementation of continuous improvement in organizations and for further research about the continuous improvement concept and process dynamics (Gilmore, 1999). Although there had been a growing interest in the implementation of continuous improvement in organizations at the end of $20^{\text {th }}$ century, Savolainen (1999) found the lack of a sound theoretical foundation for this activity. The situation has changed during the last 20 years, so the importance of continuous improvement activities gained their place not only in business practice but also in related research activities. Wu and Chen (2006) found different goals in their study of continuous improvement in organizations. (Table 1)

Table 1. Goals of continuous improvement

\begin{tabular}{|l|l|}
\hline Goals & Study \\
\hline Company-wide focus to improve process performance & Deming, 1986; Imai, 1986 \\
\hline $\begin{array}{l}\text { A gradual improvement through step by step } \\
\text { innovation }\end{array}$ & $\begin{array}{l}\text { Caffyn, 1999; Berling, 2000; } \\
\text { Brunet and New, 2003 }\end{array}$ \\
\hline $\begin{array}{l}\text { Organizational activities with the involvement of all } \\
\text { people in the company from top managers to workers }\end{array}$ & $\begin{array}{l}\text { Imai, 1986; } \\
\text { Bessant and Caffyn, 1997 }\end{array}$ \\
\hline Creating a learning and growing environment & $\begin{array}{l}\text { Pervaiz, Loh, and Zairi, 1999; } \\
\text { Delbridge and Barton, 2002 }\end{array}$ \\
\hline
\end{tabular}

Source: adapted from Wu and Chen, 2006

Other studies relate to improvement in materials (Scutaru, 204), energy use efficiency (Oh and Hildreth, 2014), process improvements (Gijo and Scaria, 2014) and environment (Comoglio and Botta, 2012). It is important to state that in recent time and (recent) research there is more studies connected to the continuous improvement methodologies such as Lean thinking (Atkinson, 2004; Wang and Huzzard, 2011; Erceg and Dotlić, 2013) Six Sigma (Linderman et al, 2003; Arnheiter and Maleyeff, 2005; Borror, 2008; Pepper and Spedding, 2010), Lean Six Sigma (Bendell, 2006; Snee, 2010; Anthony, 2011; Drohomeretski et al., 2014) than to continuous improvement 
itself. All stated researches looked at benefits companies gain from methodologies and tools and reasons for their usage.

The study conducted by Mendelbaum (2006) showed that only 11\% of companies found that their continuous improvement initiatives were successful. Operations management managers understand the significance of continuous improvement processes, but they have found that handling continuous improvement is a thoughtprovoking mission (Pullin, 2005). The biggest challenge is to create a structure for a continuous improvement projects coordination (Choo et al., 2007). Continuous improvement is a constant motion meant at increasing the level of organization-wide performance through fixated incremental process changes (Wu and Chen, 2006). One of the most important characteristics for success and competitiveness of the business is its capacity for effective implementation of continuous improvement tools and methodologies (Salah, Carretero and Rahim, 2010) and this is even more important in times when the competition on the market is increasing. Thus, the amount of process optimization and company's advancement can be significantly important not only for company's competitiveness but also for its survival. In their study, Anand et al. (2009) stated that when properly executed, the continuous improvement helps with an operational process integration and improvement of company's capability to make consistent and rapid process changes for performance improvement. They showed how initiatives for continuous improvement can be used as dynamic capabilities for improving organizational performance. Bessant et al. (2001: 75) in their conclusion stated that the continuous improvement is of considerable strategic importance, but that its management is often poorly understood. They presented stages of the evolution of continuous improvement behavior in organizations. (Table 2)

Table 2. Stages in the evolution of continuous improvement

\begin{tabular}{|l|l|}
\hline Phase & Description \\
\hline Level 0 & No continuous improvement activities \\
\hline Level 1 & Trying out the ideas \\
\hline Level 2 & Systematic Cl capability \\
\hline Level 3 & Strategic Cl capability \\
\hline Level 4 & Proactive Cl capability \\
\hline Level 5 & The learning organization \\
\hline
\end{tabular}

Source: adapted from Bessant et al., 2001

Sanchez and Blanco (2014:986) concluded that continuous improvement importance in the business environment is motivated by changes in the business environment, the emergence of new management systems and the importance of quality management itself, while Khan et al. (2018) state that the continuous improvement should be looked upon as a concept for process improvement, new ideas creation and investments in technology. 


\subsection{Different methodologies for continuous improvement}

During last several decades and due to the growing need for improvement of businesses, several continuous improvement methodologies were based on an elementary concept of process and quality improvement to simplify the production, improve quality and reduce the waste in organizations processes (Bhuiyan and Baghel, 2005). Continuous improvement researchers stated many ways for organization's processes improvement and some of them include Kaizen (Jacobson et al., 2009), Six Sigma (Anthony, Kumar and Madu, 2005), Deming Cycle (Dhafr et al., 2006), Total Quality Management (Sirinivasu et al., 2010), Balanced Score Cards (Dabhilkar and Bengtsson, 2016) and Lean Production (Deming, 2012). The most known and widely used by different industries are Lean thinking and Six Sigma. Arhneiter and Maleyeff (2005) refer to them as the-state-of-the-art methodologies and Kumar et al. (2008) state it has the biggest impact on business and processes. The third methodology Lean Six Sigma is a so-called hybrid, the result of the integration of Lean and Six Sigma (Snee, 2010). This methodology is very well accepted and known (Bhuiyan and Baghel, 2005). Continuous improvement can be achieved with the abovementioned methods in following ways: by reduction of defect rates; by reduction of response time; by products, services and operations evaluation; through the involvement of customers in product design; by productivity increasing; by quality performance improvements; by increasing employees' work commitment and by cost reduction (Khan et al. 2018).

The 20 keys methodology has been more commonly used lately. It contains 20 different tools for the continuous improvement and an increase of competitiveness. Some of the tools are part of other methods for continuous improvement activities.

\section{The 20 keys methodology}

The 20 keys methodology is based on Toyota production system (Kobayashi, 1995) and was developed in Japan in 1980-ties. It enables easier accomplishment of company's strategic goals development of human and organizational potentials and is an excellent start for the reorganization of the entire company. Bicheno (2004) defined 20 keys as a company-wide process of focused and continuous incremental innovation leading to a culture of sustained improvement and elimination of waste in all systems and processes. The name comes from 20 tools and different techniques which can be used in different situations and areas in the company. The keys are an agglomerate of different tools and techniques which are already well known in the world, but they are incorporated into a common system of evaluation, visual reporting, monitoring of results, and work organization (Dabić, Orac, Tugrul, 2016: 4). The methodology encompasses the entire company, i.e. all employees at all levels, and is focused on constant improvement. The 20 keys methodology is an integrated approach to achieving the company's strategic goals, covering all areas of business and not just individual (Gider,2004). The system encourages synergic effects within different business areas and successful and long-lasting improvements in business operations and can be an excellent introduction to lean thinking (Kobayashi, 1995). One of the goals of the 20 keys is to eliminate all the unnecessary actions, i.e. serve to direct and manage the organization about quality, delivery times and costs. (Pipunić and Grubišić, 2014) Using this method leads to increased productivity, quality enhancement, cost reduction, increased flexibility and adaptability to market changes, increased 
customer satisfaction as well as suppliers, focus on efforts to improve, grow in innovation, and ultimately leads to increased profits (Primorac, 2005). Although from the keys' names it may look like this methodology is intended only for manufacturing companies, experiences from different countries are showing that this methodology is effective also in different service companies with a small adaptation of several keys (Gider 2004). It is important to state that although 20 keys methodology is accepted worldwide there are not a lot of research papers covering the influence of the methodology on the company efficiency or competitiveness in the market (Dabić, Orac, Tugrul, 2016).

Kobayashi (1995) developed Practical Program of Revolutions in Factories (PPORF) as a result of his work with companies in their pursuit of improvement. The basic principles of implementation program of PPORF are presented in his 20 keys relations diagram where all the keys are presented together with their relationship.

Every tool (key) of this methodology is contributing to the main long-term goal which is a profit. The main consideration of every key is continuous improvement and accomplishment of the company's goals and due to methods' completeness can be considered as a quality management model. Bastleer (2011) stated four basic keys which are building a block of the methodology:

- Key 1 - cleaning and organizing - everything starts with order and cleanliness

- Key 2 - rationalizing the system/management of objectives - set goals and ensure that everybody in the company knows what his/her responsibility is to achieve these goals

- Key 3 - improvement team activities - provide a culture within which team activities can be set up to organize the improvements

- Key 20 - leading technology/site technology - everything stands and falls with the speed at which an organization can successfully adopt new technology There are 4 keys linked to the characteristics that make a production system excellent, i.e. better, faster, and cheaper. Keys 11 (quality assurance system), key 6 (manufacturing value analysis) and key 19 (conserving energy and materials) and key 4 (reducing inventory) are keys.

The main areas 20 keys are focused on can be divided into five groups. (Table 3)

Table 3. Key categories

\begin{tabular}{|l|l|l|}
\hline Group & The main goal of the keys group & Keys \\
\hline Costs & Reduction of costs & 6 Operations Kaizen \\
& & 13 Waste eliminating \\
& & 14 Employees empowerment to make \\
& improvements \\
& & 17 Control of efficiency \\
& & 19 Energy and material conserving \\
\hline Delivery & Improving the process & 5 Quick changeover technologies \\
& flow/reduction of stock / faster & 4 Lowering work-in-process (WIP) \\
& delivery & Coupled manufacturing/production \\
\hline Motivation and & Workplace energizing & 1 Cleaning and organizing to facilitate \\
security & & work \\
\hline
\end{tabular}




\begin{tabular}{|c|c|c|}
\hline Group & The main goal of the keys group & Keys \\
\hline & & $\begin{array}{l}2 \text { Alignment of goals and } \\
\text { rationalization of the system } \\
3 \text { Activities in small groups } \\
10 \text { Discipline at workplace }\end{array}$ \\
\hline Quality & Quality improvement & $\begin{array}{l}7 \text { Zero monitor } \\
\text { manufacturing/production } \\
9 \text { Machinery and equipment } \\
\text { maintenance } \\
11 \text { Assurance of the quality } \\
12 \text { Development of suppliers } \\
15 \text { Skill versatility and cross-training } \\
\end{array}$ \\
\hline Technology & Development of technology & $\begin{array}{l}18 \text { Information systems use } \\
20 \text { Leading technology/site technology }\end{array}$ \\
\hline
\end{tabular}

Source: adapted from Deloitte, 2004

If a company wants to achieve a continuous improvement and to keep the long-term business success, all previously stated keys should be implemented. However, in practice, most of the companies that are using 20 keys methodology don't introduce all keys at once. It is important to state that this methodology uses a benchmarking for its implementation and an evaluation of success rate (Dabić, Orac, Tugrul, 2016) and this is probably one of the main reasons why the concept is gaining acceptance in manufacturing organizations (Bicheno, 2004). The key to the methodology of 20 keys is that it easily evaluates and compares companies from different countries and different industrial areas (Gider, 2004). The system includes simple evaluation schemes and steps to gradually increase ratings across all 20 business areas.

De Morny (2014) found that 20 keys methodology enables every employee at all company levels to be part of their own company benchmarking. Methodology acts as an enabler for reaching constant improvement goals and simultaneously focuses on organizational climate for employees' initiative and motivation. Main benefits of implementing 20 keys methodology are enhancing competitiveness, market share, customer satisfaction and profitability (Kobayashi, 1995; Petrarolo, 1997; Dabić, Orac, Tugrul, 2016).

The methodology is most widely spread in Japan, from where it has expanded in Europe during the last decade. With adaptations to European culture, it was introduced by German, Dutch, British, and Spanish companies.

\section{Research methodology}

The research presented in this paper was conducted within one Croatian company. First part of the research was done with the help of management board with whom we have done secondary research i.e. used company information for creation of analyses of different keys influence on improving company's efficiency. We have used internal checklists from production (i.e. education lists, mold change lists, energy use data and invoices for used energy, injury reports, a suggestion for improvement data, profit-loss statements, etc.) Primary data were edited using MS 
Excel software. During the examination of the documents, we used basic statistics techniques to prepare graphs.

For the second part of our research, we made interviews with several employees working for the examined company. With secondary research, we have received basic information and statistical data about 20 keys methodology influence on organizational efficiency. Interviews were used to get employees own insights about what company has accomplished. Since this paper is focused on company's and employees' perception, conducting interviews helped us to get more qualitative information on changes before and after 20 keys methodology implementation.

For the interviews, we used the CAPI method. This is interviewing technique where interviewer uses a computer for answering questions and is preferred over telephone interviews. During the second part of the research, we have interviewed 8 employees (i.e. $2,2 \%$ of the total number of employees) from the different backgrounds and working in the different management levels. Since the research was done with the approval of the managing board, the sample was intentionally created by the company who gave us the list of the people with whom we did interviews. The way the sample was created and the number of the people in the sample is one of the deficiencies of our research. In our sample, we had 7 men and 1 woman since the Plamen mainly employs men. Their age was from $20-30$ (3); 31-40 (3) and 41-50 (2). For most of the interviewed people, (6) Plamen was the only workplace of and for two this was the second place of employment. Out of 8 interviewed employees, 1 was a member of the board who oversaw the project implementation, 2 were middle management and remaining 5 were production workers.

The research instrument consisted of eight questions starting with demographics and position in the company. Next, we asked about their involvement in 20 keys implementation project and their opinion about it. Finally, we were interested to hear about their insights about changes 20 keys brought to the company in total, influence on their work position and to them as an individual. Each of the interviews lasted for 25 minutes and they took place in May 2017. The interview questions allowed more profound understandings of how 20 keys influenced changes in employees' behavior and improved organizational efficiency.

\section{Implementation of $\mathbf{2 0}$ keys methodology in Plamen Požega}

The 20 keys methodology was implemented in more than 40 companies in Croatia between 2004 and 2010. Croatian Ministry of Economy, Labor, and Entrepreneurship partially financed the implementation of the methodology (Ministarstvo gospodarstva, rada i poduzetništva, 2004) and Delloite was the company in charge of implementation. Dabić, Orac, and Tugrul (2016) conducted a research on companies that implemented 20 keys in Croatia in which they have been looking for changes in performance, growth in revenue and increase in employee's motivation. The research showed that companies which had implemented 20 keys produce better financial results and higher rates of growth in relation to the standard figures of Croatian companies within the same industries. 
One of the companies that implemented 20 keys methodology was Plamen Požega. Company Plamen has 85 years long tradition of production of cast iron products. They are one of the largest iron foundries and biggest and only producer of household appliances in the domain of heating bodies in Croatia. The foundry produces various types of cast iron castings for own need and for sales, in accordance with quality standards EN-GJL 200 and EN-GJL 250. Annual production is about 20,000 tons. It specializes in the production of thin castings, as a component of stoves, ovens, boilers, and fireplaces. Based on the tradition of skills and knowledge and with the application of modern technology, a home appliance factory has been developed, with an annual production of 60,000 units. Most of the program refers to individual heating of rooms - stoves, fireplaces and solid fuel stoves. The company is privately owned and employs around 370 workers. Plamen is an export-oriented company and over $70 \%$ of production is exported to the EU and other European countries.

The company introduced a 20-key method to increase productivity, quality, reduce costs, increase flexibility and to adapt to market changes and more efficiently respond to customer requirements. It is important to state that the company doesn't need to implement all available keys. They worked on keys which would have had the greatest influence on the company performance when implemented and thus, they only implemented following keys: $1,3,4,5,6,8,10,11,12,13,15,16$ and 19. In the next part of the paper, we will discuss how the implementation of keys influenced Plamen's performance and help them in increasing their competitiveness.

\subsection{Keys 1 and 10 - Cleaning \& Organizing / Time Control \& Commitment}

Plamen continued with conduction security checks in the company. During this period 50 checks were conducted in Enamel section and they involved 230 employees. Noticed security problems were corrected either immediately by workers themselves or in agreement with maintenance and top management.

Total number work-related injuries have dropped significantly since the year 2000 when there was 53, to 10 in 2009 (start of 20 keys project) and to only 1 in 2015. Risk assessment was made for every workplace with the goal to harmonize the employment contracts with the needs of the work organization and occupational safety. The process of risk assessment included all stakeholders (different departments, employees, management) and they looked upon all possibilities (new employees starting to work in Plamen, change of the workplace, return from sick-leave, imminent threat of disability, etc.) of potential work injuries.

\subsection{Key 3 - Small group activities}

Every employee can contribute to the workplace advancement with their knowledge and useful suggestions. Therefore, employees are encouraged to speak honestly and openly through which they can cooperate more effectively and jointly and with that making it easier to solve the problems that have arisen. Through such a relationship a growing sense of belonging to the group and encouraging the competitive spirit. Small-group meetings are held daily with topics such as yesterday's results, today's plan, problems, achievements, information gathered by the group supervisor which could be interesting for a department. During 2015 employees made 246 suggestions for improving work process in the company out of which 123 has been accepted. From the start of the project, employees made more than 2.200 suggestions 
out of which 1106 has been accepted. It is important to state that every employee whose suggestion had been accepted was rewarded financially. Most of the suggestions were given in June and December of each year.

\subsection{Key 11 - Quality Assurance}

The aim of Key 11 is the creation of a work environment focused on discovering the root cause of the problem and developing faultless production. Seven quality control tools help the company in finding the underlying causes of errors and preparing and introducing SOP (standard operating procedures) for removal of recognized errors. The company uses fishbone diagrams to focus efforts on finding the cause of problems that offer the greatest potential for improvement. They focus on the content of the problem, include a team that builds support for the resulting solution and it is important to focus on causes rather than symptoms. Pareto analysis is also used to identify, investigate and visually present all the possible causes associated with the problem as the major cause was discovered. This analysis helps them focus on the greatest impact of the cause, based on the principle that $20 \%$ of the source causes $80 \%$ of the problem, and visually displays the relative importance of the problem. The checklist enables the team to systematically collect and process data to clearly determine the pattern and trends. This creates intelligible data, a clearer picture of the facts, and marks the patterns inside the data. The company was looking for the satisfaction of their buyers and the average grade of buyer's rating in 2015 was 3.13 while the target set for 2015 was 3.14. This result has been increasing steadily from 2010 when the 20 keys implementation started so this change can also be related to the project.

\subsection{Key 5 - Quick Changeover Technology}

The company tested scoring threads with a tap for gray cast iron which can be used for scoring threads without lubricants. The test was carried out on the casting EK-87 with the Cherry basement using the M6 marked TICN M6. The usage of new taps showed improvement for 5 seconds in production time of the operation. It is important to state that these TICM M6 taps are more expensive than regular taps as they are making savings in time of drilling cast iron. For this test, the company used 1016 drip-molding with 4 threads and that is a total of 4064 threads. The total of time-saving was 1,41 hours for a tested number of pieces. This increases a work productivity and allow the company to finish the job faster and save workers time for other products, therefore, making this product cheaper.

\subsection{Key 12 -Developing your Suppliers}

Activities undertaken within this key contain work on intensifying communication with external suppliers to find new, more favorable, suppliers and provide new competitive bidders for more materials. Eventually, more favorable suppliers were found, and savings were made, but the quality of the equipment ordered never came in question. With a saving on supply side company was able to invest in the technology and marketing and lower the price of a final product which made them more competitive on the market. 


\subsection{Key 15 - Skill Versatility and Cross Training}

The variety of skills, gained through planned training, contribute to the faster achievement of company's plans and goals, but also facilitates responses to customer requirements. All the groups together had set a 260-point improvement plan, out of which 213 was achieved or $81.92 \%$ of the planned. The best groups were: drilling (23 of 23 planned points), foundry 2 (22 of 24) and foundry 3 (23 of 25) and on the other side groups with the smallest achievements include: montage (3 out of 6), supply (5 out of 9 ) and model (4 out of 7 ).

\subsection{Key 19 -Conserving Energy and Materials}

The focus of this key is on saving energy and materials to increase a cost efficiency and continuously increase profitability.

Table 4. Cost of energy (electrical energy and gas)/kg of good products

\begin{tabular}{|c|c|}
\hline Year & Cost (HRK/kg) \\
\hline 2013 & 1,43 \\
\hline 2014 & 1,15 \\
\hline 2015 & 1,10 \\
\hline
\end{tabular}

Source: authors research, 2017

From 2013 to 2015 there has been a decline in electricity consumption per ton of melted cast from $613 \mathrm{kWh}$ to $601 \mathrm{kWh}$. It is important to state that the electricity consumption in 2009 before implementation of 20 keys methodology was $641 \mathrm{kWh} / \mathrm{t}$ of the melted cast and in 2002 it was $840 \mathrm{kWh} / \mathrm{t}$. The company has managed to decrease a use of electricity in 6 years for more 6\%. Key 19 led to a significant reduction in energy consumption per ton of melted cast. Along with the increase of production during the examined period, the company saved more than $300.000 \mathrm{HRK}$ in electricity consumption only.

5.8. Other keys: 4, 8, 16 - Flow keys (Reducing Work-In-Progress, Coupled Manufacturing, Production scheduling); 6/13 - Kaizen of Operations / Eliminating Waste

The company set a goal for value of Work-In-Progress (WIP) for 2015 at 5,1 million HRK. Currently, the value of WIP is around 7 million HRK so the company should do some work to lower a WIP inventory and reach set goals which will help the free the money currently frozen in the WIP inventory.

Figure 1 shows the increase in value-added activities in different departments of the company. This increase means that there is less waste in company's processes. This is the result of the continuous improvements company have been doing in accordance with keys 6 and 13. Results from those keys help the company in establishing and preparation of Standard operating procedures (SOP) representing currently the best possible way of doing certain tasks and activities in the company. These documents include tasks, basic steps, quality checks, protective gear and needed education. SOP is a starting point for further improvement activities and they are evaluated by the employees. 


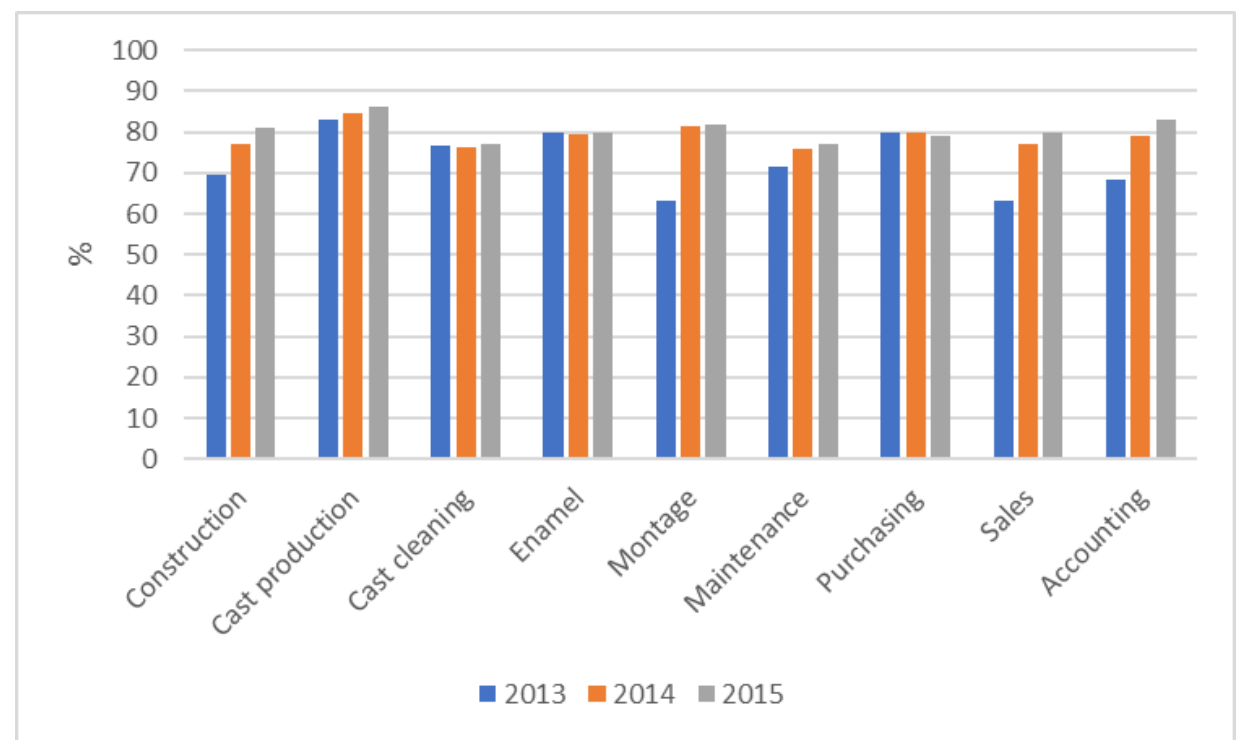

Fig. 1. Value added activities change

Source: authors research, 2017

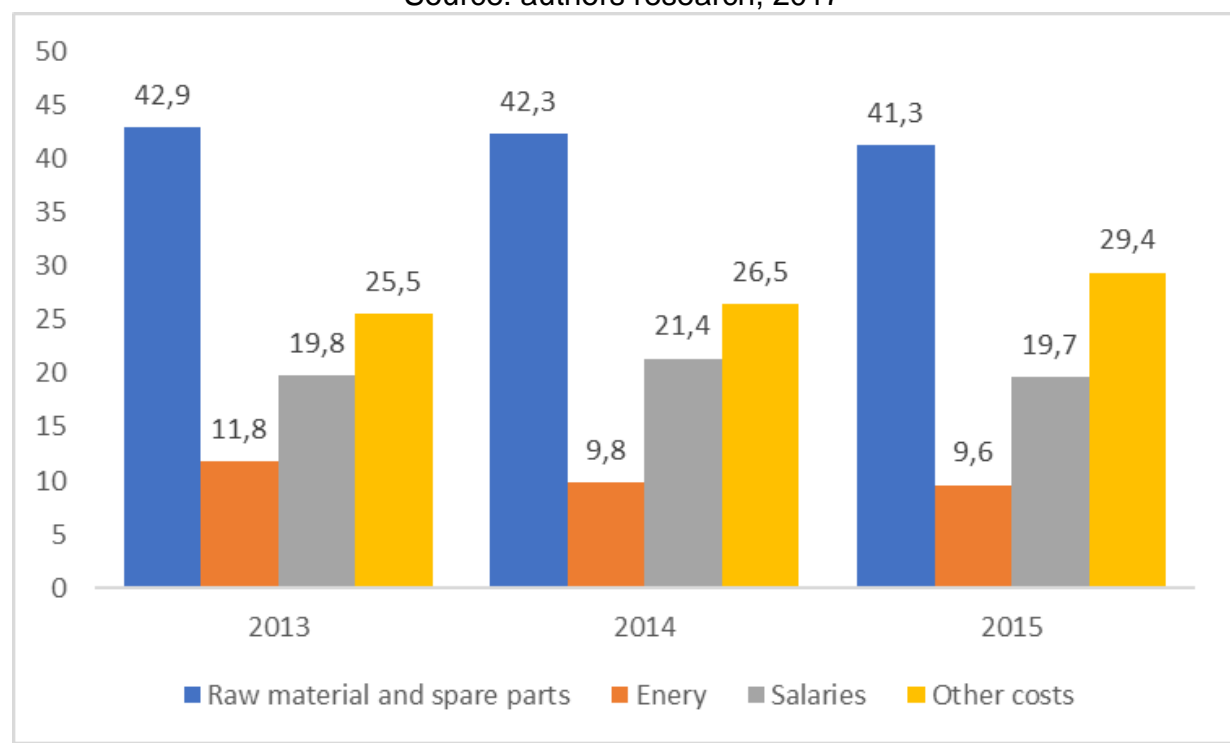

Fig. 2. Company costs

Source: authors research, 2017

Figure 2 presents company costs in Plamen from 2013 to 2015. Data presented shows a decrease of all costs despite the production growth. This indicates that the use of 20 keys is helping the company in decreasing costs of business while helping it to grow. 


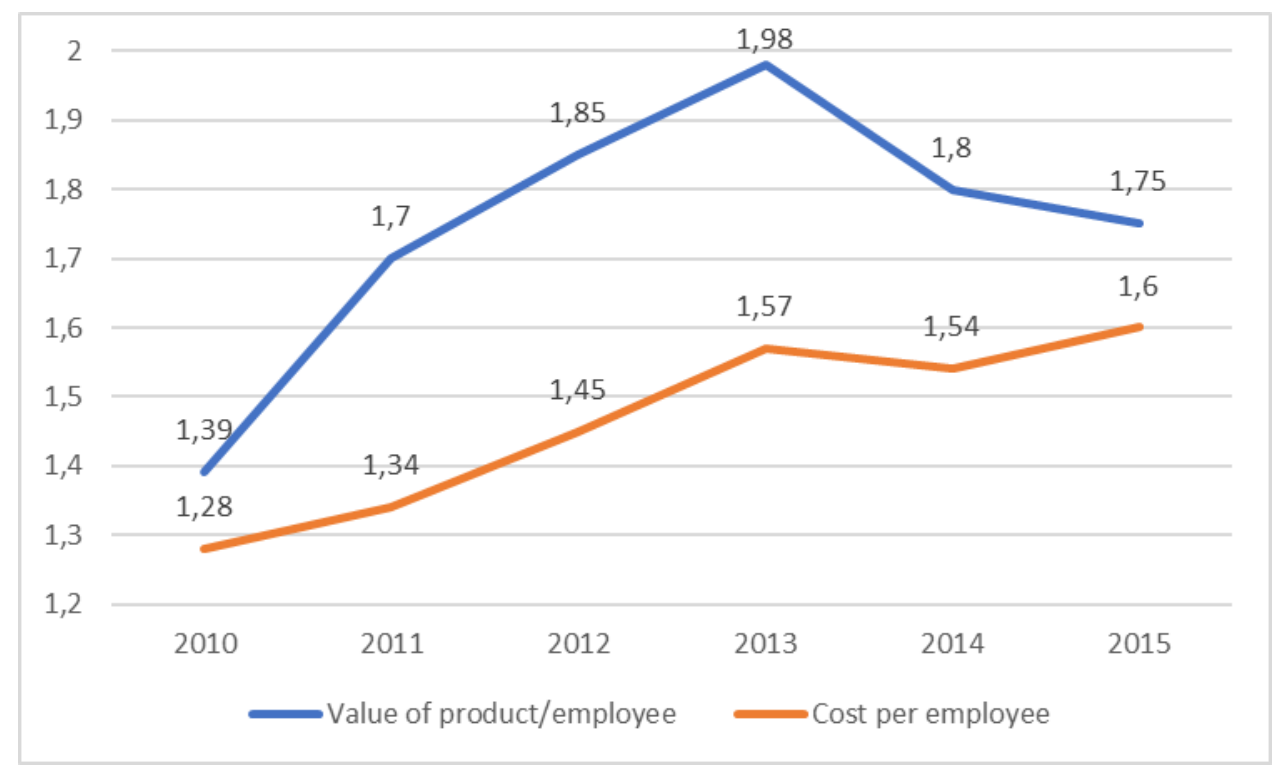

Fig. 3. Productivity indicators

Source: authors research, 2017

There is the growth of productivity indicators is present from the time company started 20 keys implementation (a difference between a value of production/employee in relation to cost/employee). This difference is lower in last year due to the project stagnation i.e. less work on some of the 20 keys.

Previous information about keys implemented by Plamen Požega shows that the company managed to increase the productivity, lower costs, increase the sales due to the increased quality of its products and in total increase the competitiveness.

\subsection{Qualitative findings}

During the second phase of our research, we interviewed several employees of Plamen Požega working at the different levels of the company. Most of them were workers in production, two were from middle management, and one was a member of the company's managing board.

Most of the interviewed employees are directly involved in the production and they were not enthusiastic about the project of 20 keys methodology implementation. This was mainly due to the different projects they had in the past, which did not bring any improvements to the company's results. When the project started they noticed a difference in implementation, since this project had a strong support from the company's managing board, due to its perceived potential benefits. This reluctant attitude was confirmed during the interview with one of the board members, who also stated that the implementation of the 20 keys methodology completely changed the way employees approached their jobs and work obligations. The improvement of the organizational efficiency and savings done with the implementation of the methodology were the most important benefits according to the board member. 
During the implementation, there were several barriers which the project team needed to pass due to needed changes in organizational and employees' behavior. This "resistance" is present in almost every company since people don't like to change their work habits and especially if they have been working for a longer time in the same position. The workers in production appreciated the newly installed skills versatility training since it could have presented a change in their work positions. Workers training influenced the improvements in process of changing molds in production - it increased the speed of it. This has improved organizational efficiency and shortened a production time - i.e. producing more in a shorter time. The production employees saw the benefits of the project and considered the most important to be the attitude of the project manager during project implementation. They could have expressed their ideas for increasing efficiency and they were rewarded if the idea was accepted and resulted in the improvement of the business process. The changes achieved during the project influenced the changes in work behavior and increased the work security since all employees were better trained for their jobs.

Plamen management board's favorite key was work and partnership with suppliers. This key had a significant influence on possible savings in purchasing and on possible quality improvements of the final products. Cooperation with suppliers resulted in a lower stock level in Plamen and increased quality of purchased materials. According to the managing board member, the main benefits of the 20 keys project refereed to the fact that: the production cycle time was shortened, the quality of the products was improved, the total cost of production was lowered, and the organizational efficiency was increased. With all these achieved, the company was able to be more competitive on the market with the possibility to lower the prices of their products.

\section{Concluding remarks and recommendations for further research}

Companies can and use different management tools and methodologies for a continuous improvement to achieve strategic goals and increase organizational efficiency through the enhanced speed of learning and innovation and process and quality improvements. Although many companies are satisfied with early results of the improvement, the continuous improvement approach requires a constant and long-term engagement to reach a sustainable growth.

The implementation of the 20 keys methodology is an excellent start for the reorganization of the entire company because it is a company-wide process that creates a culture of sustained improvement. This methodology allows the company to make a systematic improvement based on organizations' strength. The 20 keys methodology strong point is its implementation as a central way of workplace management and can only be accepted through the devoted and dedicated application.

The review of the analyzed 20 keys implementation showed improvements in organizational efficiency in all observed areas - from safety, human potential development, time and money savings. This is mainly because employees saw and understood a direct connection between project activities and the project results. The support of the management board was of crucial importance for the success of this project. Results showed that a continuous improvement is the outcome of on-going activities and company needs to continue with their efforts in implementing and maintaining this methodology.

The results of this paper emphasize what the 20 keys methodology implementation can contribute to companies by increasing organizational efficiency. As it was 
previously stated the research about the 20 keys methodology didn't gain momentum in academic circles as some other continuous improvement methodologies. Therefore, the results of this research give contribution to the better understanding of the methodology and its influence on improvement of the companies' efficiency especially in following fields: change of employees' way of thinking, alignment of goals at all levels, more functional jobs, elimination of scrap losses, unnecessary downtime and machine failures, continuous work on improving the technological process of production and reorganizing part of the technological process. 20 keys methodology can additionally influence companies' competition due to the improvements it has made in the examined company but to confirm this statement further research should be made.

Further research is recommended to examine if the 20 keys implementation has had a similar influence in different Croatian industrial sectors; to establish a methodology impact on organizational efficiency and whether the implementation can lead to the improved competitiveness and to further monitor company Plamen and its results with implemented methodology during a next period of time.

\section{References}

Antony, J. (2011) Six Sigma vs Lean: Some Perspectives from Leading Academics and Practitioners, International Journal of Productivity and Performance Management, 60 (2): 185-190.

Arnheiter, E.D., Maleyeff, J. (2005) Research and concepts: the integration of Lean management and Six Sigma, The TQM Magazine, 17 (1): 5-18.

Atkinson, P. (2004) Creating and Implementing Lean Strategies, Management Services, 2, 18-22.

Batsleer. J. (2011) 20 keys to workplace improvement. Available at: http://www.amelior.be/ ndl/artikels/artikel.asp?c $=4 \& s c=0 \& a=171 \& t c=1$ (accessed on April 24, 2017).

Bendell, T. (2006) A review and comparison of Six Sigma and the lean organizations, The TQM Magazine, 18(3): 255-262 Snee, R. D. (2010) Lean Six Sigma - getting better all the time, International Journal of Lean SixSigma, 1 (1): 9-29.

Bessant, J., Caffyn, S. (1997) High involvement innovation through continuous improvement, International Journal of Technology Management, 14 (1): 7-28.

Bessant, J., Caffyn, S., Gallagher, M. (2001) An evolutionary model of continuous improvement behavior, Technovation, 21, 67-77.

Bessant, J., Caffyn, S., Gilbert, J., Harding, R. Webb, S. (1994) Rediscovering continuous improvement, Technovation, 14 (1): 17-29.

Bhuiyan, N., Baghel, A. (2005) An overview of continuous improvement: from the past to the present, Management Decision, 43 (5): 761-771.

Bicheno, J. (2004) The New Lean Toolbox, Picsie Books, Buckingham, United Kingdom.

Borror, C. M. ed. (2008) The Certified Quality Engineer Handbook, ASQ Quality Press, Milwaukee, USA.

Choo, A. S., Linderman, K. W., Schroeder, R. G. (2007) Method and context perspectives on learning and knowledge creation in quality management, Journal of Operations Management, 25 (4): 918-931.

Comoglio, C., Botta, S. (2012) The use of indicators and the role of environmental management systems for environmental performances improvement: a survey 
on ISO 14001 certified companies in the automotive sector, Journal of Cleaner Production, 20 (1): 92-102.

Dabić, M., Orac, M., Tugrul, U. D. (2016) Targeting sustainable competitiveness in Croatia by the implementation of " 20 Keys" methodology, Journal of Innovation and Entrepreneurship, 5 (10): 1-26.

Deloitte CE (2004) Priručnik za upravljanje ključevima, Deloitte CE, Zagreb, Croatia.

Deming, W. E. (2012) The new economics: For industry, government, education, Technometrics, 38 (3): 294-295.

DeMorny, C. (2014). The role of Management Support and Shared Understanding of 20 Keys for Continuous Improvement: An employee perspective. Master's thesis defended at School of Business and Finance in the Faculty of Economic and Management Sciences at the University of the Western Cape. Available at: http://etd.uwc.ac.za/xmlui/handle/11394/3899 (accessed on April 20, 2017).

Dhafr, N., Ahmad, M., Burgess, B., Canagassababady, S. (2006) Improvement of quality performance in manufacturing organizations by minimization of production defects, Robotics and Computer-Integrated Manufacturing, 22 (5): 536-542.

Drohomeretski, E., Gouvea da Costa, S. E., Pinheiro de Lima, E., da Rosa Garbuio, P. A. (2014) Lean, Six Sigma and Lean Six Sigma: an analysis based on operations strategy, International Journal of Production Research, 52 (3): 804824.

Erceg, A., Dotlić, P. (2013) Lean Thinking as Way of Improving Efficiency of Croatian SME's. In: Grbac, B., Lončarić D., Dlačić, J. (Eds.) Proceedings of 23rd Cromar Congress - Marketing in a Dynamic Environment - Academic and Practical Insights Lovran, Croatia, pp. 37-51.

Gider F. (2004) Poboljšanje konkurentnosti tvrtki pomoću sustava 20 ključeva, Intelektualni kapital, 1-9, 20-21.

Gijo, E. V., Scaria, J. (2014) Process improvement through Six Sigma with Beta correction: a case study of manufacturing company, International Journal of Advanced Manufacturing Technology, 71 (1-4): 717-730.

Gilmore, H. L. (1990) Continuous Incremental Improvement: An Operations Strategy for Higher Quality, Lower Costs, and Global Competitiveness, SAM Advanced Management Journal, Winter, 21-25.

Ivanova, A., Gray, J., Sinha, K. (2014). Towards a unifying theory of management standard implementation: the case of ISO 9001/ISO 14001, International Journal of Operations \& Production Management, 34, 1269-1306.

Jacobson, G. H., Mccoin, N. S., Lescallette, R., Russ, S., Slovis, C. M. (2009) Kaizen: A method of process improvement in the emergency department, Academic Emergency Medicine, 16 (12): 1341-1349.

Khan, H. U., Ali. S., Hongqi, L. (2018) Impact of Continuous Improvement on Organization Performance Insight from Pakistan: An Empirical Study, International Journal of Innovation, Management and Technology, 9 (1): 7-14.

Kobayashi, I. (1995) 20 Keys to Workplace Improvement (Manufacturing \& Production): Productivity press, Portland, Oregon.

Kumar, U. D., Nowicki, D., Ramírez-Márquez, J. E., Verma, D. (2008) On the optimal selection of process alternatives in a Six Sigma implementation, International Journal of Production Economics, 111 (2): 456-467.

Linderman, K., Schroeder, R., Zaheer, S. and Choo, A. (2003) Six sigma: a goal theoretic perspective, Journal of Operations Management, 21 (2): 193-203.

Mendelbaum, G. (2006) Keep your eye on the ball, APICS Magazine, January. 
Ministarstvo gospodarstva, rada i poduzetništva. (2004). Međunarodna konferencija o povećanju konkurentnosti. Available at http://www.mingorp.hr, (accessed March 25, 2017)

Pepper, M. P. J., Spedding, T. A. (2010) The evolution of lean Six Sigma, International Journal of Quality \& Reliability Management, 27 (2): 138-155.

Petrarolo, D. (1997). Benchmarking Organizational Capability using the 20 Keys, The South African Journal of Industrial Engineering, 8 (2): 16-32.

Pipunić, A., Grubišić, D. (2014) Suvremeni pristupi poboljšanjima poslovnih procesa i poslovna uspješnost, Ekonomska misao i praksa, 23 (2): 541-572

Primorac, Ž. (2005) Povećanje konkurentnosti hrvatskog gospodarstva (metoda 20 ključeva): Microsoft business productivity conference, Zagreb, Croatia.

Pullin, J. (2005) Room for improvement, Professional Engineering, 18 (15): 38-138.

Salah, S., Carretero, J. A., Rahim, A. (2010) The integration of quality management and continuous improvement methodologies with management systems, International Journal of Productivity and Quality Management, 6 (3): 269-287.

Sanchez, L., Blanco, B. (2014) Three decades of continuous improvement, Total Quality Management, 25 (9): 986-1001.

Savolainen, T. I. (1999) Cycles of continuous improvement - Realizing competitive advantages through quality, International Journal of Operations \& Production Management, 19 (11): 1203-1222.

Scutaru, M. L. (2014) Toward the use of irradiation for the composite materials properties improvement, Journal of Optoelectronics and Advanced Materials, 16 (9-10): 1165-1169.

Seong-Chan, O., Hildreth, A. J. (2014) Estimating the Technical Improvement of Energy Efficiency in the Automotive Industry - Stochastic and Deterministic Frontier Benchmarking, Energies, 7 (9): 6196-6222.

Sheridan, J. H. (2000) Lean Sigma' synergy, Industry Week, 249 (17): 81-82.

Snee, R. D. (2010) Lean Six Sigma - getting better all the time, International Journal of Lean SixSigma, 1 (1): 9-29.

Srinivasu, R., Reddy, G. S., Sreenivasarao, V., Rikkula, S. R. The contributions of TQM and Six Sigma in the organizations to achieve the success in terms of quality, International Journal of Computer Applications, 8 (4): 24-28.

Teece, D. J., (2007) Explicating dynamic capabilities: nature and micro-foundations of (sustainable) enterprise performance, Strategic Management Journal, 28 (11): 1319-1350.

Wang, Y., Huzzard, T. (2011) The Impact of Lean Thinking on Organizational Learning, Organization Learning, Knowledge and Capabilities Conference - Making Waves, Hull, United Kingdom.

Wu, C. W., Chen, C. L. (2006) An integrated structural model toward successful continuous improvement activity, Technovation 26 (5/6): 697-707. 